\title{
PROGRAM APLIKASI ALAT PENGUKUR KADAR GLUKOSA DALAM DARAH NON INVASIVE BEBASIS DESKTOP
}

\author{
Marwa Sulehu ${ }^{1}$, Ahmad Harun Senrimang ${ }^{2}$ \\ Sistem Infromasi STMIK AKBA ${ }^{1,}$ Teknik Informatika STMIK AKBA ${ }^{2}$ \\ Email: marwa.sulehu@akba.ac.id ${ }^{1}$, harun.akba2013@gmail.com²
}

\begin{abstract}
ABSTRAK
Alat yang umum digunakan untuk mengukur kadar gula darah adalah glucometer berbasis sensor kimia dengan enzim glucose oxidase sebagai bahan aktifnya dan alat tersebut memerlukan sampel darah. Ada dua metode dalam pengukuran gula darah, yaitu dengan menggunakan metode invasive dan metode non-invasive.metode invasive memerlukan sampel darah dengan cara mengeluarkan darah setelah jari ditusuk dengan jarum, sedangkan metode non-invasive tidak memerlukan pembedahan untuk mendapatkan sampel darah, dengan menggunakan LED merah dan infrared sebagai sumber cahaya serta sensor fotodioda maka sampel darah dalam tubuh bisa dibaca dan dilakukan pengukuran pada ujung jari. Penelitian ini bertujuan untuk merancang dan mengimplementasikan program aplikasi alat pengukur kadar glukosa dalam darah non invasive pada Poliklinik Bhayangkara Resort Pangkep berbasis desktop dimana alat tersebut fungsi utamanya sama dengan alat glucometer, dan tidak perlu dilakukan pembedahan untuk pengambilan sampel darah tapi menggunakan sensor fotodioda yang diletakkan pada ujung jari dan sebagai outputnya digunakan personal computer (PC). Hasil dan pengukuran yang telah dilakukan akan tersimpan didalam database. Data ini diperoleh melalui penelitian lapangan, Pustaka dan wawancara.Data dianalisis dengan pemrograman, alat menggunakan Inframerah dan fotodioda sebagai sumber sensor, Arduino Nano sebagai pemrosesan data dan interface aplikasi menggunakan Borland Delphi 7. Hasil Penelitian ini menunjukkan bahwa alat pengukur kadar glukosa dalam darah secara non-invasive dengan Infrared sebagai sumber cahaya serta Fotodioda sebagai sensornya dapat memberikan informasi kadar glukosa dalam darah dengan rata-rata persentase akurasi sebesar 94,9\% pada penggunaan jari telunjuk kiri dan hasil pengukuran dapat ditampilkan pada aplikasi berbasis desktop berupa angka, selain itu biodata pasien beserta hasil pengukuran dapat tersimpan ke dalam database aplikasi.
\end{abstract}

Kata Kunci :glukosa, invasive, non-invasive, inframerah, fotodioda,arduino nano, desktop.

\begin{abstract}
A common tool used to measure blood sugar levels is a chemical-based glucometer with a glucose oxidase enzyme as its active ingredient and the device requires a blood sample. There are two methods in measuring the blood sugar, namely the invasive and non-invasive methods. The invasive method requires a blood sample by removing the blood after the finger is pierced with a needle, while the non-invasive method does not require surgery to obtain a blood sample by using the red and infrared LEDs as a light source and photodiode censor The blood sample in the body can be read and measured at the fingertips. The aims of the study were to design and implement a non-invasive glucose level of the measurement
\end{abstract}


application program at Poliklinik Bhayangkara Resort Pangkep based on desktop where the tool is primarily the same function as a glucometer device, and there is no need for surgery for blood sampling but using a photodiode censor placed on fingertips and as the output used personal computer (PC). The measurement result that have been done will be stored in the database. The data was obtained through field research, library research and interview. The data was analyzed by using programming, tools using Infrared and photo diode as censor source, Arduino Nano as data processing and the application interface using Borland Delphi 7. The results of the study indicated that the measuring device of non-invasive blood glucose with Infrared as a light source and Photodioda as the sensor can provide the information about the blood glucose levels with an average accuracy percentage is $94.9 \%$ on the use of the left index finger and the measurement results can be displayed on desktop-based applications in the form of numbers. In addition, the patient's data and the measurement results can be stored into the application database.

Keywords: glucose, invasive, non-invasive, infrared, photodiode, arduino nano, desktop.

\section{Pendahuluan}

Alat yang umum digunakan untuk mengukur kadar gula darah adalah glucometer berbasis sensor kimia dengan enzim glucose oxidase sebagai bahan aktifnya. Alat tersebut memerlukan sampel darah. Cara mengambil sampel dengan cara mengeluarkan darah setelah jari ditusuk dengan jarum, metode ini disebut sebagai metode invasive.

Pengukuran gula darah secara invasive tidak bisa diterapkan pada semua pasien, pasien yang mengalami gangguan mental atau takut terhadap benda tajam bukan merupakan sebuah pilihan yang tepat untuk dilakukan. Bagi pasien yang mengalami penyakit diabetes melitus atau rusaknya pangkreas yang tidak bisa memproduksi insulin akan membutuhkan pengontrolan/pengawasan kadar gula darah, dengan menggunakan metode invasive maka akan menyebabkan infeksi serta pendarahan jika dilakukan secara berulang-ulang dan dari segi ekonomi, tentunya pasien yang berekenomi rendah tidak dapat melakukan pemeriksaan secara rutin karena uji laboratorium dan penggunaan strip pada alat tersebut membutuhkan biaya yang cukup besar jika dilakukan secara terus menerus. Disamping itu data hasil pengukuran hanya bisa ditampilkan sekali pada display alat sehingga pencatatan datanya masih manual baik itu diinput secara manual pada komputer maupun ditulis tangan pada media kertas.

Pengukuran gula darah dengan menggunakan metode non-invasive tidak memerlukan pembedahan untuk mendapatkan sampel darah. Dengan menggunakan LED merah dan infrared sebagai sumber cahaya serta sensor fotodioda maka sampel darah dalam tubuh bisa dibaca dan dilakukan pengukuran pada ujung jari. Pada penelitian sebelumnya yang dilakukan oleh Khairunnisa (2014), mengenai Rancang Bangun Alat Ukur Kadar Gula Darah Non Invasive Berbasis Sensor Fotodioda, dijelaskan bahwa Pengujian alat rancangan terhadap variasi kadar gula darah menunjukkan bahwa nilai intensitas cahaya yang diterima sensor fotodioda yang direpresentasikan oleh nilai tegangan output akan mengalami perubahan seiring dengan berubahnya nilai kadar gula darah, sehingga dapat disimpulkan bahwa sensor fotodioda dapat berfungsi dengan baik sebagai sensor alat ukur kadar gula darah non-invasive.

Dari permasalahan tersebut maka akan dilakukan penelitian dengan judul "Program 
Aplikasi Alat Pengukur Kadar Glukosa Dalam Darah Non Invasive Bebasis Desktop"

\section{Kajian Pustaka}

\subsection{Program Aplikasi/Software}

Perangkat Lunak adalah

instruksi-instruksi (program computer) yang ketika dijalankan menyediakan fiturfitur, fungis-fungsi dan kinerja-kinerja yang dikehendaki; (2) struktur data yang memungkinkan program-program memanipulasi informasi (3) informasi deskriptif pada salinan tercetak dan bentuk-bentuk maya yang menggambarkan pengoperasian dan penggunaan programprogram.[16]

\subsection{ADC (Analog To Digital Converter)}

ADC (Analog To Digital Converter) adalah perangkat elektronika yang berfungsi untuk mengubah sinyal analog (sinyal kontinyu) menjadi sinyal digital. Perangkat ADC (Analog To Digital Convertion) dapat berbentuk suatu modul atau rangkaian elektronika maupun

suatu chip IC. ADC (Analog To Digital Converter) berfungsi untuk menjembatani pemrosesan sinyal analog oleh sistem digital.

Alat bantu digital yang paling penting untuk teknologi kontrol proses adalah yang menerjemahkan informasi digital ke bentuk analog dan juga sebaliknya. Sebagian besar pengukuran variabelvariabel dinamik dilakukan oleh piranti ini yang menerjemahkan informasi mengenai vaiabel ke bentuk sinyal listrik analog. Untuk menghubungkan sinyal ini dengan sebuah komputer atau rangkaian logika digital, sangat perlu untuk terlebih dahulu melakukan konversi analog ke digital (A/D). Hal-hal mengenai konversi ini harus diketahui sehingga ada keunikan, hubungan khusus antara sinyal analog dan digital.

Analog To Digital Converter (ADC) adalah pengubah input analog menjadi kode - kode digital. ADC banyak digunakan sebagai Pengatur proses industri, komunikasi digital dan rangkaian pengukuran/ pengujian. Umumnya ADC digunakan sebagai perantara antara sensor yang kebanyakan analog dengan sistim komputer seperti sensor suhu, cahaya, tekanan/ berat, aliran dan sebagainya kemudian diukur dengan menggunakan sistim digital (komputer).

\subsection{Arduino Integrated Development Environment (IDE)}

Arduino integrated development environment terdiri dari editor teks untuk menulis kode, sebuah area pesan, sebuah konsol, sebuah toolbar dengan tomboltombol untuk fungsi yang umum dan beberapa menu. Arduino integrated development environment terhubung ke arduino board untuk meng-upload program dan juga untuk berkomunikasi dengan arduino board.

Perangkat lunak yang ditulis menggunakan integrated development environment disebut sketch. Sketch ditulis pada editor teks. Sketch disimpan dengan file berekstensi ino. Area pesan memberikan memberikan informasi dan pesan error ketika kita menyimpan atau membuka sketch. Konsol menampilkan output teks dari Arduino integrated development environment dan juga menampilkan pesan error ketika kita mengkompile sketch. Pada sudut kanan bawah dari jendela Arduino integrated development environment menunjukkan jenis board dan port seriak yang sedang digunakan. Tombol toolbar digunakan untuk mengecek dan mengupload sketch, membuat, membuka atau menyimpan sketch, dan menampilkan serial monitor.[19]

\section{Metode Penelitian}

metode pengumpulan data dilakukan dengan beberapa cara yaitu :

\section{a. Observasi}

Melakukan observasi pada alat pengukur kadar glukosa invasive yang ada di poliklinik. 


\section{b. Studi literatur}

metode pengumpulan data dilakukan beberapa sumber seperti perpustakaan atau literatur-literatur yang akan menjadi pendukung bagi peneitian.

\section{c. Wawancara}

metode pengumpulan data ini dilakukan dengan memberi pertayaan secara langsung kepada pihak Poliklinik Bhayangkara Resort Pangkep.

\subsection{Gambaran Umum Sistem}

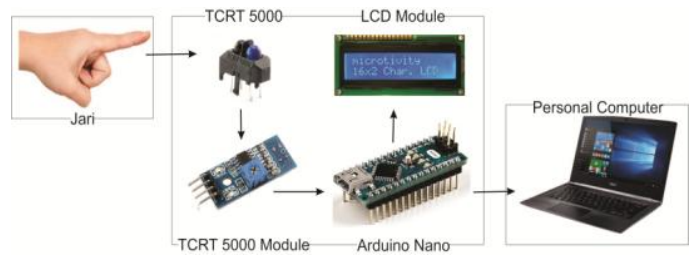

Gambar 1 Gambaran Umum Sistem

perangkat lunak ini juga dirancang untuk menyimpan data hasil pengukuran kedalam database. Pada gambar 1 merupakan gambaran umum sistem dimana pasien akan melakukan pengukuran kadar glukosa pada ujung jari yang ditempelkan pada sensor alat.

\subsection{Perancangan Hardware}

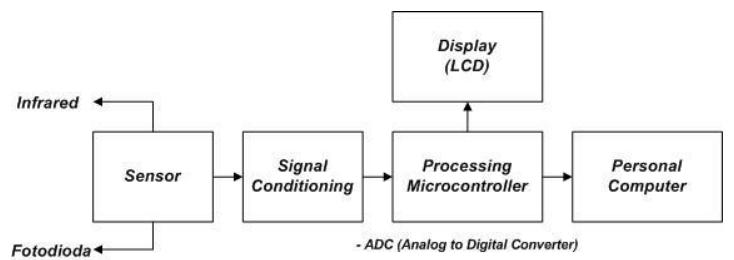

Gambar 2 Diagram blokfungsional alat rancangan

Pada gambar 2dirancang diagram yang menggambarkan bagian-bagian alat dalam bentuk blok fungsional untuk mempermudah proses perancangan hardware.

\subsubsection{Perancangan Alat}

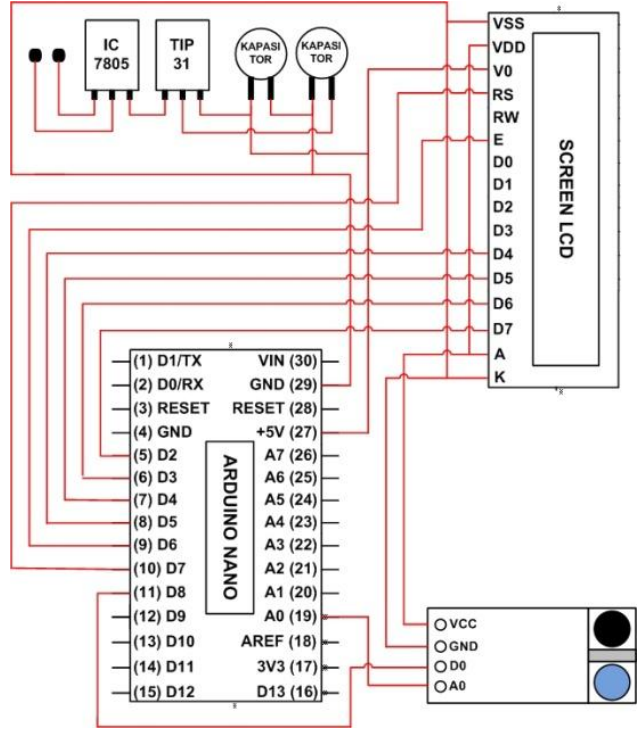

Gambar 3Perancangan Alat

Untuk dapat membangun alat pengukur kadar glukosa, tahap awal yang dilakukan menghubungkan TCRT 5000, Arduino Nano dan LCD. port pada TCRT 5000 perlu dihubungkan dengan port yang sesuai dengan port pada Arduino Nano dan $L C D$.

\subsubsection{Flowchart Sistem Alat}

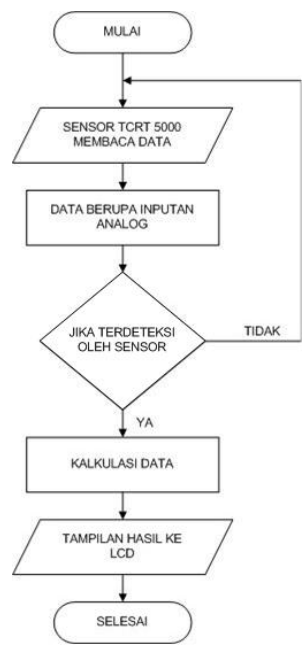

Gambar 4 Flowchart Sistem Alat Pengukur Glukosa

Pada saat alat ini dijalankan maka tahap pertama yang dilakukan adalah pembacaan data dari sensor TCRT 5000 pada ujung jari, data yang diterima berupa inputan analog. Jika senyawa glukosa tidak 
terdeteksi oleh sensor maka proses akan kembali lagi ke tahap awal untuk melakukan pembacaan data, ketika senyawa glukosa terdeteksi oleh sensor maka akan otomatis dilakukan kalkulasi data dan hasilnya akan ditampilkan ke LCD.

\subsection{Perancangan $U M L$}

\subsubsection{Use Case Diagram}

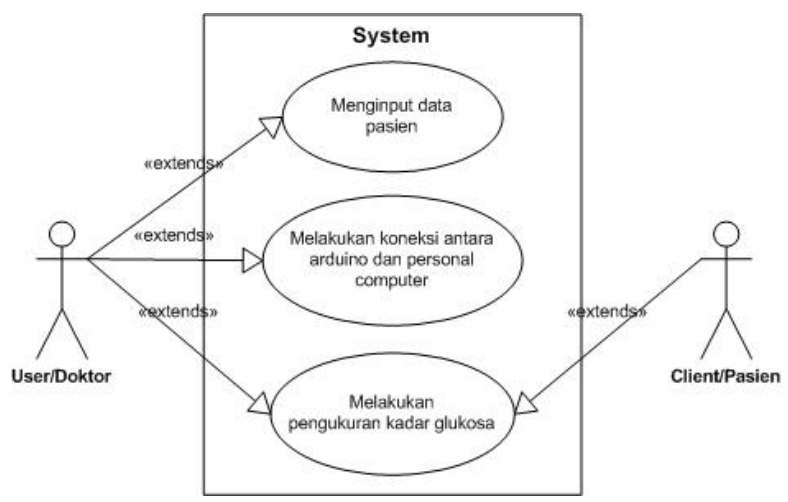

Gambar 5 Use Case Pengukur Kadar Glukosa

\subsubsection{Activity Diagram}

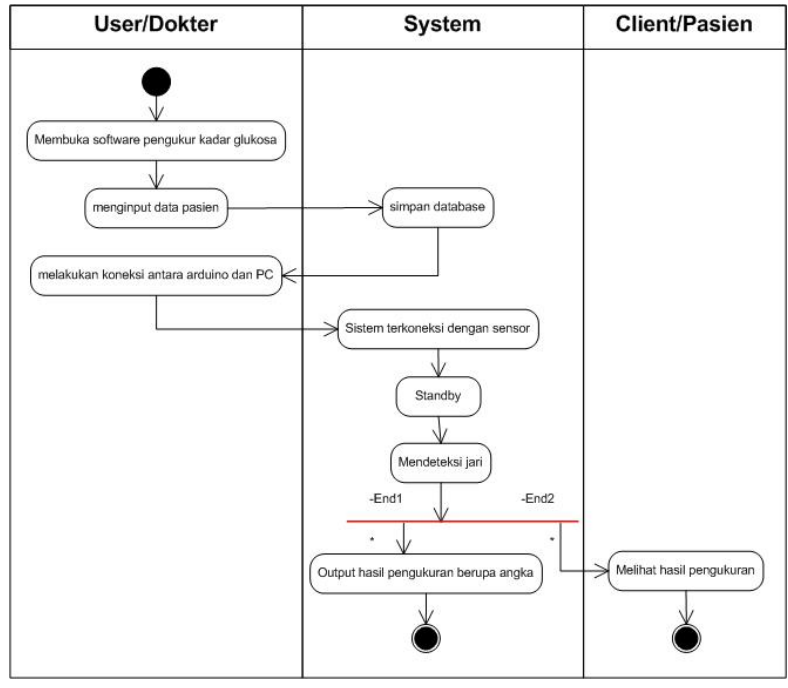

Gambar 6 Activity Diagram Pengukur Kadar Glukosa

\subsubsection{Sequence Diagram}

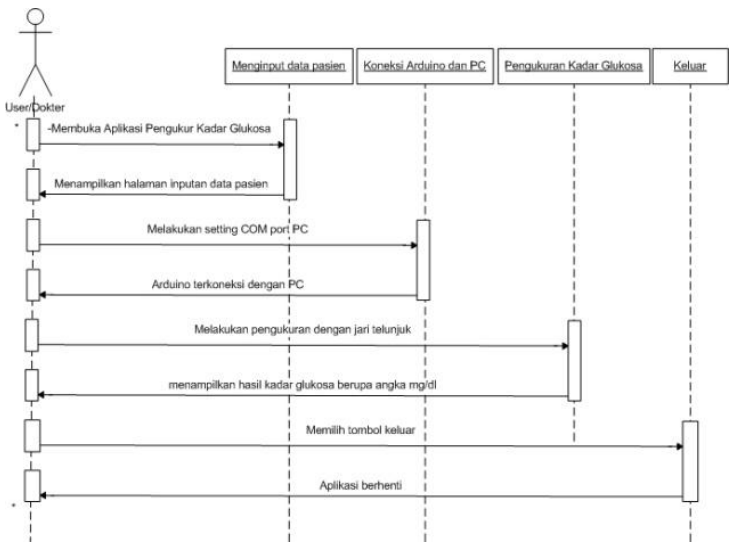

Gambar 7 Sequence Diagram Pengukur Kadar Glukosa

\subsection{Perancangan Software}

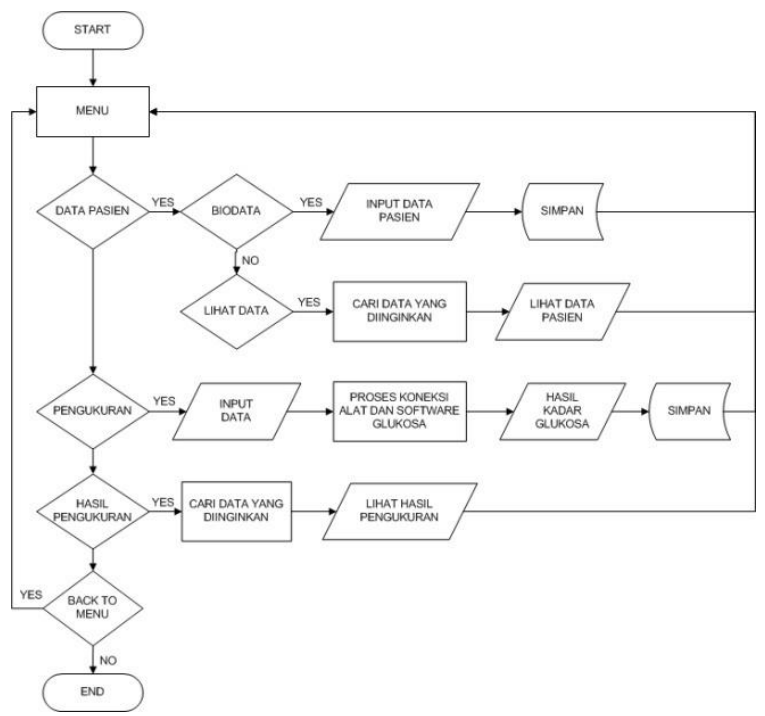

Gambar 8 Flowchart Sistem Software Pengukur Glukosa

Pada saat software dijalankan, proses pertama adalah pemilihan menu yaitu menu data pasien, pengukuran dan hasil pengukuran. Lalu saat memilih menu data pasien maka akan muncul dua pilihan yaitu menu biodata atau lihat data. Di menu biodata dilakukan proses inputan data dan menyimpannya ke database, sedangkan di lihat data menampilkan data pasien yang telah disimpan sebelumnya. Pada menu pengukuran dilakukan proses 
masukan data dari data pasien dan kemudian akan dilakukan pengukuran kadar glukosa yang telah terhubung dengan alat gula darah dan hasilnya akan tersimpan di database. Dan pada menu hasil pengukuran menampilkan data informasi pasien yang telah melakukan pengukuran sebelumnya.

\section{HASIL DAN PEMBAHASAN}

\subsection{Hasil Perancangan}

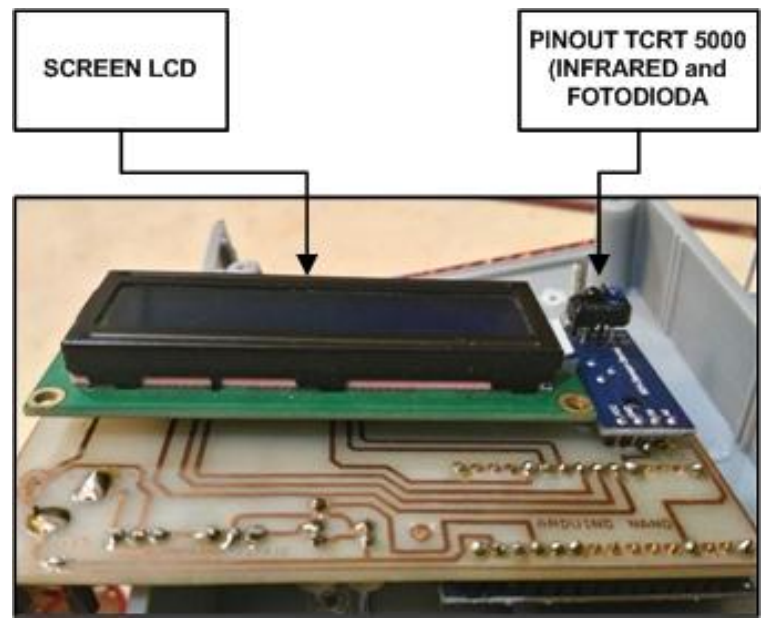

Gambar 9Tampilan Depan Alat Pengukur Glukosa

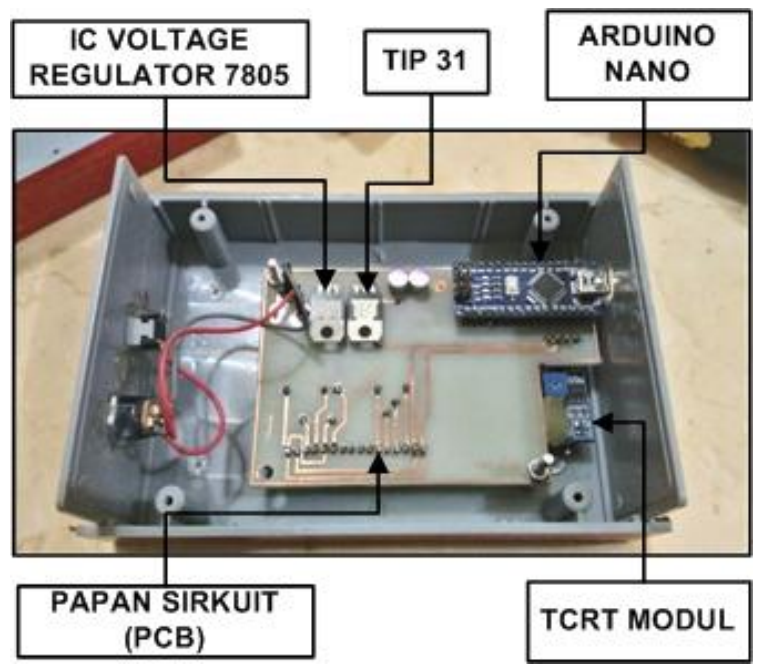

Gambar 10Tampilan Belakang Alat Pengukur Glukosa

Pada gambar 9 dan 10 komponen bahan telah terpasang pada box casing menggunakan solder dan lem tembak untuk memperkuat pemasangan komponen alat. Pada gambar 3.3 adalah hasil perancangan alat yang terhubung pada PC.

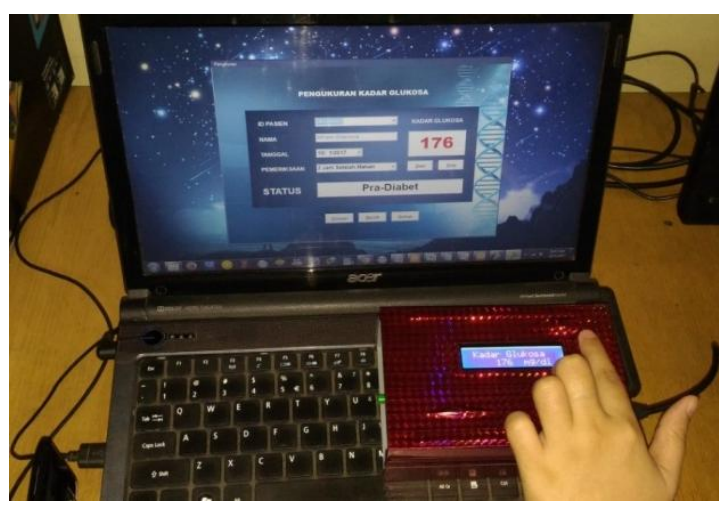

Gambar 11 Hasil Perancangan Hardware yangTerhubung Ke Personal Computer

$(P C)$

Berikut ini adalah tampilan hasil pembuatan software pada PC yang berfungsi untuk menampilkan data hasil pengukuran kadar oksigen dalam darah. Pembuatan software ini menggunakan bahasa pemograman Borland Delphi 7 dan database Mysql yang dibuat menggunakan Xampp yang berfungsi untuk menyimpan data hasil pengukuran. Berikut ini adalah tampilan beberapa formsoftware pengukur gula darah.

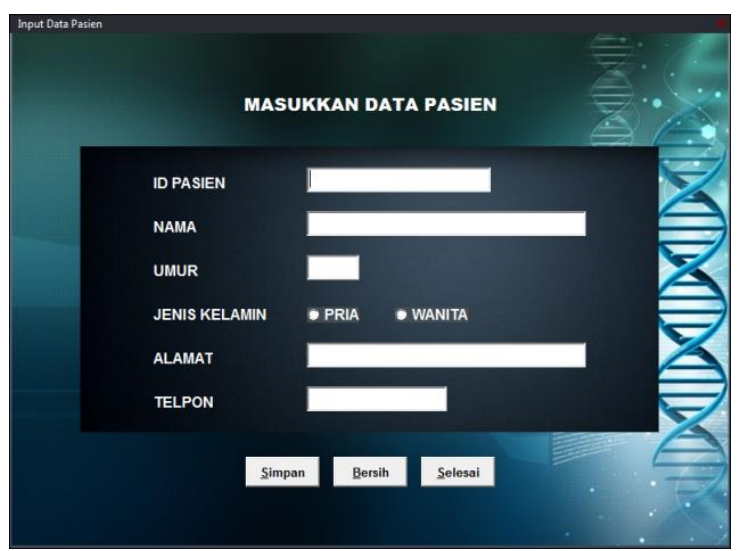

Gambar 12 Menu Input Data

Gambar 12 merupakan Forminput data berfungsi untuk memasukkan data 
informasi pasien yang akan menggunakan program ini.

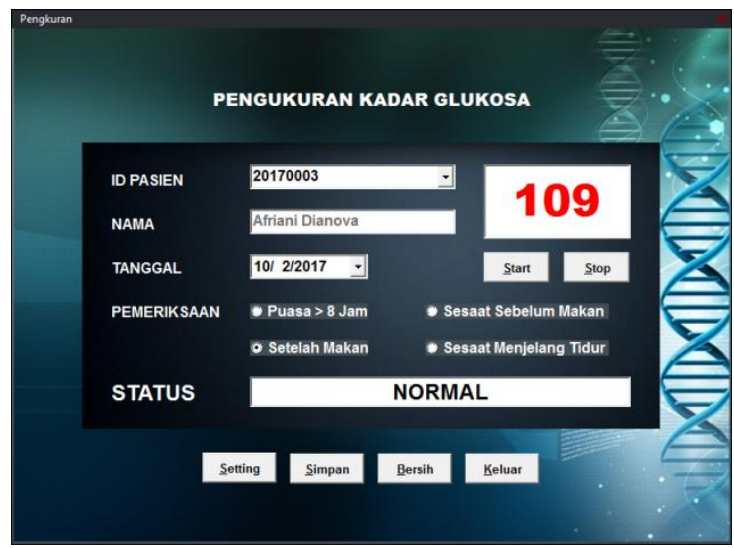

Gambar 13Form Pengukuran

Gambar 13 merupakan Form pengukuran merupakan form yang digunakan untuk mengukur kadar glukosa dalam darah, alat pengukur glukosa yang telah dibuat akan dihubungkan dengan personal computer sehingga dapat berkomunikasi pada usb serialport, hasil kadar glukosa yang didapatkan oleh alat akan ditampilkan pada form ini. Pada form ini terdapat tombol start yaitu untuk membuka koneksi port agar dapat terhubung dengan alat dan stop untuk menutup koneksi.

\subsection{Pengujian Alat}

Pengujian ini dilakukan untuk menjalankan sistem secara keseluruhan. Pengujian dilakukan dengan menjalankan program (software) dan alat (hardware) yang telah dibuat. Pengujian dilakukan dengan mengambil 10 sample data dari 10 orang yang berbeda. Data yang didapat dari pengukuran menggunakan sistem secara keseluruhan dapat dibandingkan dengan perhitungan alat gula darah invasiveyaitu NESCO Multichecksehingga dapat dihitung presentase error.

Berdasarkan Penelitian yang dilakukan oleh Riza Tamridho (2011), yang berjudul "Rancang Bangun Alat Pengukur Kadar Gula Darah" menggunakan rumus penghitungan peresentase akurasi pengukuran sebagai berikut :

$\%$ Akurasi $=\frac{\text { AlatyandDibuat }- \text { AlatStandar }}{\text { AlatStandar }} \times 100 \%$

Tabel 1 Data Hasil Percobaan

\begin{tabular}{|c|l|c|c|c|c|}
\hline \multirow{2}{*}{ No } & \multirow{2}{*}{ Nama } & $\begin{array}{c}\text { Umur I } \\
\text { Jenis } \\
\text { Kelamin }\end{array}$ & Kadar Glukosa & Persentase \\
\cline { 4 - 5 } & & 25/ W & 136 & 142 & 95,7 \\
Akurasi
\end{tabular}

Tabel 2Menurut Waktu Pemeriksaan

\begin{tabular}{|c|c|c|c|c|}
\hline \multirow[b]{2}{*}{ No } & \multirow[b]{2}{*}{ Nama } & \multirow{2}{*}{$\begin{array}{c}\text { Umur I } \\
\text { Jenis } \\
\text { Kelamin }\end{array}$} & \multicolumn{2}{|c|}{ Kadar Glukosa Alat Buatan } \\
\hline & & & $\begin{array}{l}\text { Setelah } \\
\text { Makan }\end{array}$ & Puasa $>8$ Jam \\
\hline 1 & Sampel 1 & $17 / \mathrm{L}$ & 111 & 106 \\
\hline 2 & Sampel 2 & $17 / \mathrm{L}$ & 115 & 109 \\
\hline 3 & Sampel 3 & $16 / \mathrm{L}$ & 104 & 95 \\
\hline 4 & Sampel 4 & $20 / L$ & 120 & 118 \\
\hline 5 & Sampel 5 & $22 / \mathrm{L}$ & 148 & 142 \\
\hline 6 & Sampel 6 & $32 / \mathrm{L}$ & 168 & 168 \\
\hline 7 & Sampel 7 & $17 / \mathrm{L}$ & 110 & 104 \\
\hline 8 & Sampel 8 & $21 / L$ & 114 & 108 \\
\hline 9 & Sampel 9 & $32 / \mathrm{L}$ & 220 & 184 \\
\hline 10 & Sampel 10 & $19 / \mathrm{L}$ & 164 & 160 \\
\hline
\end{tabular}

\section{Kesimpulan}

Dari hasil perancangan, implementasi dan pengujian didapatkan kesimpulan aitu telah dibuat alat pengukur kadar glukosa dalam darah secara noninvasive dengan Infrared sebagai sumber cahaya serta Fotodioda sebagai sensornya dengan rata-rata persentase akurasi sebesar 94,9\% pada penggunaan jari telunjuk kiri. Hasil pengukuran dapat ditampilkan pada aplikasi yang terdapat pada personal computer berupa angka, selain itu biodata pasien beserta hasil pengukuran dapat tersimpan ke dalam database aplikasi.

Untuk kedepannya, Pemakaian alat ukur gula darah ini tidak digunakan untuk penunjuk kesehatan yang akurat. Untuk itu 
perlu pertimbangan, penelitian, pengujian, dan pengembangan lebih lanjut. Perancangan perlu ditingkatkan mulai dari penentuan nilai serapan optimal gula darah, pembentukan probe untuk mentransmisikan cahaya dan pemilihan komponen. Untuk menghasilkan tujuan penelitian yang lebih baik dan menghasilkan sinyal yang lebih baik maka disarankan untuk menggunakan sensor yang memiliki spesifikasi yang lebih baik. seperti photodiode dan komponenkomponen yang memiliki kinerja yang lebih baik, sehingga dapat diperoleh nilai kalibrasi yang lebih akurat. Selain itu, perlu dilakukan perancangan ulang probe sensor yaitu dengan cara membuat jarak yang konstan antara sensor dengan sumber cahaya. Selanjutnya sangat disarankan untuk menggunakan sumber cahaya yang memiliki intensitas yang tinggi sehingga daya penetrasi cahaya tinggi akan menghasilkan tingkat akurasi yang lebih baik

\section{Referensi}

[1] ADC (Analog To Digital Converter), Prinsip Dan Jenis ADC. (n.d.). Retrieved September 28, 2017, from http://zonaelektro.net/adc-analog-todigital-converter/

[2] Anwar, B. I., Patmasari, R., Elektro, F. T., \& Bandung, U. T. (2015). Dalam Darah Secara Non-Invasive Design and Implementation NonInvasive Measuring Device of Glucose Level in Blood, 3(3), 3-6.

[3] ARDUINO NANO | arduino ku. (n.d.). Retrieved September 29, 2017, from https://djukarna4arduino.wordpress.c om/2015/01/19/arduino-nano/

[4] Astawa, I. M. (2016). sistem instrumentasi alat ukur kadar gula darah non invasive, (November),1-3.

[5] Dinata, Yuwono Marta. 2014. Arduino Itu Mudah. Jakarta: PT. Elex Media Komputindo.
[6] Djojodibroto, D. R. (2001). Seluk Beluk Pemeriksaan Kesehatan . Jakarta: Pustaka Populer Obor.

[7] Ferdiansyah. 2012. Golongan Darah

[8] Fisika, J., \& Universitas, F. (2013). Rancang Bangun Alat Ukur Kadar Gula Darah Non- Invasive Berbasis Mikrokontroler At89S51 Dengan Mengukur Tingkat Kekeruhan Spesimen Urine Menggunakan Sensor Fotodioda, 2(1), 40-47.

[9] Frank D. Petruzella., 2001, Elektronika Industri, Penerbit Andi, Penerjemah Suminto, Drs. MA., Yogyakarta.

[10] Fredy, F. C. (n.d.). Gula darah adalah-Fungsi-Kelainan (Kerjanya). Retrieved July 19, 2017, fromhttp://www.kerjanya.net/faq/53 23-gula-darah.html

[11] Jogiyanto. 2001. Analisis \& Desain Sistem Informasi :pendekatan terstruktur teori dan praktek aplikasi bisnis. Andi, Yogyakarta.

[12] Khairunnisa Z. Rancang Rancang Bangun Alat Ukur Kadar Gula Darah Non Invasive Berbasis Sensor Fotodioda [skripsi]. Bogor (ID): Institut Pertanian Bogor.2014.

[13] Kusnassriyanto, 2011. Belajar Pemrograman DELPHI. Bandung: Modul Bandung

[14] Lanywati, E. 2001. Diabetes Mellitus : Penyakit Kencing Manis. Yogyakarta : Kanisius ( Anggota IKAPI ).

[15] Lau, W.S. (1999). karakterisasi inframerah untuk mikroelektronik. World Scientific.

[16] Presman, Roger S. (2012). "Rekayasa Perangkat Lunak Buku Satu pendekatan praktisi edisi 7".Yogyakarta: Penerbit ANDI.

[17] Purbakawaca R. Rancang bangun alat ukur gula darah non-invasive berbasis microcontroller ATMEGA32A [skripsi]. Bogor (ID): Institut Pertanian Bogor.2013. 
[18] Sabrina Q. Kajian Sifat Optis pada Glukosa Darah [skripsi]. Jakarta (ID): Universitas Islam Negeri syarif Hidayatullah.2013.

[19] Santoso, Hari. 2015. Arduino Untuk Pemula V1. Tersedia: http://www.elangsakti.com/2015/07/ ebook-gratis-belajar-arduinopemul .html. Diakses pada tanggal 12 Januari 2017.

[20] smart_ebook: Sinar Infra Merah (Infra Red Ray). (n.d.). Retrieved September 28, 2017, from http://smartpustaka.blogspot.co.id/20 11/02/sinar-imfra-merah-infra-redray.html

[21] Solichin, Achmad. 2010. Mysql 5 Dari Pemula Hingga Mahir. Jakarta: Universitas Budi Luhur.

[22] Tamridho, R. (2011). Rancang bangun alat pengukur kadar gula darah. Universitas Indonesia, 2.

[23] Wahana Komputer. 2009. Panduan Aplikatif dan Solusi (Aplikasi Cerdas Menggunakan Delphi), Semarang. Penerbit: Andi Offset, Yogyakarta. 